\title{
К.Л. Ковригина
}

Новосибирский государственный педагогический университет

\section{В поисках скрытой истины Пруст-переводчик ${ }^{1}$}

Аннотация: В данной статье мы показываем, насколько важной для становления Пруста как писателя была его работа над переводом произведений Рескина. Наше исследование позволяет также доказать необходимость прочтения «Поисков» как «романа-палимпсеста».

In this article we show the importance of Proust's work as an interpreter of Ruskin and prove that the books of the English author helped him to work out his own artistic destiny. Our research demonstrates Proust's novel as a «palimpsest».

Ключевые слова: перевод, препятствие, текст, чтение.

Translation, truth, obstacle, text, reading.

УДК: 821.133.1.

Контактная информация: Новосибирск, ул. Вилюйская, 28. НГПУ, кафедра русской литературы и теории литературы. Тел. (383) 2680630. E-mail: asiakovrigina@gmail.com.

Роман «В поисках утраченного времени» можно кратко охарактеризовать как произведение, повествующее о постепенном раскрытии истины. «Всецело устремленное к прозрению Сущностей, оно в то же время не перестает удаляться от них, и именно из этой неуловленной истины, из этого отнятого обладания у произведения и рождается шанс обрести свою истинную силу обладания» [Женетт, 1998 , c. 151].

Поиск скрытого смысла является для Пруста не только моделью, согласно которой он выстраивает свою книгу, но и служит моделью письма. Если учесть, что слово «текст» происходит от латинского «textus» - ткань, сплетение, то роман Пруста есть не что иное, как туго сотканное полотно, где, словно нити, переплетаются и накладываются друг на друга множество смыслов и значений.

В. Бенжамин, переводивший «Поиски», называл эту книгу «языковым Нилом» [Benjamin, 1983, p. 125]. Истина Пруста извилиста, она доступна не всякому и открывается не всем, произведение Пруста ждет вдумчивого читателя: «Безусловно, редко случается, что произведение искусства состоит сплошь из таких непонятных, неожиданно ощущаемых истин, надобно эту истину обрамить простой оправой» [Proust, 1982, p. 173]. Пруст стремится «придать фразе такой же вес, как и у воспроизводимых объектов, придать ей плотность, в которой пребывала бы «тайная сущность», ускользающая от восприятия, но чье скрытое присутствие мы должны ощутить в прозрачном тесте текста» [Женетт, 1998, с. 82].

«Прозрачное тесто текста» - идеальная формула, выведенная Берготом. «Вот как мне надо было писать, - сказал он. - Мои последние книги слишком сухи, на них нужно наложить несколько слоев краски» [Пруст, 1990, с. 182]. Эта грустная предсмертная фраза писателя обладала бы огромной ценностью, если бы только

\footnotetext{
${ }^{1}$ Текст дается в авторской редакции.
} 
Бергот знал, как именно накладывать краски слоями, как писать не «вширь», а «вглубь». Но Бергот не успел этого узнать, он не умел наслаивать в своих текстах значение на значение, как в своих картинах, художник Вермеер накладывал мазок на мазок. Этого не умел и молодой Пруст. Проработав четыре года над романом «Жан Сантей», он признал свой провал, неспособность найти общего плана, главной мысли, что объединяла бы разрозненные эпизоды. Тогда, чтобы забыть о неудаче, Пруст обращается к творчеству Рескина: «...мир, представший вдруг перед моими глазами, бесценен. И мое восхищение Рескином придало такой значительности вещам, что мне казалось, что в них больше ценности, чем в самой жизни» [Proust, 1965, p. 139].

В декабре 1899 года Пруст сообщает Мари Нордлинжер: «Вот уже пятнадцать дней я занимаюсь небольшой работой совершенно отличной от всего, что я делал до этого, она касается Рескина и нескольких церквей» [Nordlinger, 1942, p. 5-6]. С Мари, кузиной Рейнальдо Ана, Пруст знакомится в 1986 году, в год публикации книги «Утехи и дни». Она станет его верным и безвозмездным помощником в работе над Рескином (Мари откажется ставить свое имя на переводах).

Книги «мастера красоты» не были переведены на французский. Раньше Пруст читал лишь отрывки из произведений Рескина в журналах le Bulletin de l'Action morale и La Revue de deux Mondes. Пруст не отличался хорошим знанием английского, а значит, перевести Рескина для него было единственной возможностью его прочитать.

Мари Нордлинжер утверждает: «Пруст не знал английского» [Ibid., p. VIII] В письме к Константину де Бранковану, писатель поясняет: «Я учил английский, когда у меня были приступы астмы и я не мог говорить, <..> я выучил его глазами, я не знаю, как произносить слова и не могу распознать слов, когда их произносят. Я не настаиваю на том, что я знаю английский язык. Я настаиваю на том, что я знаю Рескина» [Proust, 1932, p. 221].

По свидетельствам друзей, других авторов на английском языке Пруст не читал.

Позже Пруст посмеется над самим собой в одном из пастишей: «Мы проследили перевод “Издания Путешественников” сделанный Прустом. <...> М. Пруст, кажется, не отдает себе отчета, в присутствующих в его тексте противоречиях, так как много раз, в слишком частых примечаниях, он горячо благодарит директора театра, телефонистку, двух членов общества Скачек с препятствиями, за помощь в прояснении непонятных ему отрывков» [Proust, 1971, p. 78].

Для нас важно знать, как именно Пруст работает над переводом. Сначала, он просит свою мать, Госпожу Пруст, перевести текст дословно ${ }^{1}$; затем, Мари Нордлинджер дорабатывает этот перевод, исправляет первый слой текста, придавая ему смысл и единство мысли; и, наконец, за текст принимается сам Пруст, он тщательно ищет каждый нюанс оригинала и отбрасывает все, что ему кажется неверным, неистинным. Этот сложный ритуал похож на некое «раздевание» текста или на снятие краски, мазок за мазком, дабы восстановить скрытый смысл самого глубокого слоя рукописи-палимпсеста, и дабы, предположим, изучить технику многослойного письма. Итак, текст Рескина поучает Пруста, как поучает Бергота «кусочек желтой городской стены» на картине Вермеера.

В августе 1905 года, когда Пруст правит гранки «Сезама и Лилии», его постигает внезапное озарение и он видит как разрешить проблему, помешавшую ему закончить роман «Жан Сантей». Свои мысли он набрасывает в форме длинного предисловия к «Сезаму и Лилии», к которому мы еще вернемся. Но тогда

\footnotetext{
${ }^{1}$ Мари Нордлинжер о работе Мадам Пруст: «требовалось..., чтобы его мать... перевела текст слово в слово, заполняя своим изящным почерком бесчисленные зеленые, желтые, красные школьные тетради» [Nordlinger, 1942, p. VIII].
} 
у Пруста не было ни возможности, ни времени взяться за работу. Вскоре умирает его мать и Марсель проводит два года в бездействии. Только в январе 1908 г. он начинает писать роман.

Первые черновые наброски «Поисков» - блокнот от 1908 г, опубликованный Филиппом Кольбом. Этот блокнот можно рассматривать как лингвистический эквивалент Мадленки, его страницы доказывают, что именно в этот период одухотворенный Пруст разрабатывает принцип будущего произведения. «Рваные», короткие фразы - скорее телеграфный стиль - свидетельствуют, насколько лихорадочно он записывал свои мысли ${ }^{1}$.

Среди этих заметок Пруста есть небольшой отрывок, посвященный поэтике перевода, где Пруст рассматривает письмо именно как феномен «глубины», а исходный текст как некую скрытую в самой себе книгу, которую трудно разобрать: «То, что неясно представляется нам в глубине сознания, прежде чем воплотиться в произведении, прежде чем выйти наружу, необходимо заставить его пересечь промежуточный отрезок между нашим темным я и внешним, нашим разумом, но как его туда довести, как уловить? <...> Мы можем часами стараться вернуть первое впечатление, тот неуловимый знак, что был в нем, и который будто бы говорил: углубись в меня, не приближаясь, не приходя. И все-таки это - искусство, это - единственное искусство» [Proust, 1976, p. 102].

Наверное, логическим завершением этой мысли можно считать следующую фразу из «Обретенного времени»: «Только искусство сможет проявить для других и показать нам самим внутреннюю жизнь, «наблюдению» не поддающуюся, - ее видимые проявления подлежат переводу, а зачастую и чтению в обратном порядке, трудоемкой расшифровке. И тогда работа, проделанная самолюбием, страстью, подражательным духом, абстрактным интеллектом, привычками, будет уничтожена искусством, пустившимся в обратный путь, вернувшимся к глубинам, где погребена неведомая нам реальность, - искусство заставит нас найти ее». [Пруст, 1999, р.122]. И, наконец, вывод, к которому приходит рассказчик: «...единственно правдивую книгу большой писатель должен не выдумывать в расхожем смысле этого слова (поскольку она живет в каждом из нас), но переводить. Долг и задача писателя - долг и задача переводчика» ${ }^{2}$ [Пруст, 1999, p. 118].

Можно утверждать, что огромная работа по расшифровке текстов Рескина стала моделью и подсказала метод создания «Поисков». Сам перевод был, прежде всего, поисками; Пруст погружался в неуловимые знаки на незнакомом языке за которыми, скрывалась истина Рескина. Он рассматривал «непереводимое» не как некую ценность и не как препятствие или повод для отчаяния, но как постоянное «вопрошание текста».

Переводческий метод Пруста можно смело определить как герменевтический. Герменевтика, как мы знаем, происходит от понятия, служащего интерпретации библейских текстов. Применительно к Библии герменевтика означает выявление чувственно-буквального и идеально-мистического смыслов текста, надо почувствовать истину между строк, найти в тексте божественное послание, которое открывается далеко не всем. Фридрих Шлейермахер определяет герменевтику как «искусство избежать недопонимания», а Жорж Стайнер заявляет в своем труде «После Вавилона», что «понять - это и есть перевести» [Steiner, 1975].

\footnotetext{
${ }^{1}$ Позже Пруст будет старательно затирать это ощущение внезапного озарения в тягучих фразах-периодах «Поисков».

2 Утверждение о том, что задачи писателя и переводчика идентичны, не ново для литературы: об этом говорили Новалис, Бодлер, Валери: «Писать чтобы то ни было... - это работа по переводу, абсолютно сравнимая с переносом текста с одного языка на другой» [Valery, 1957, p. 24]
} 
В одном из своих писем Пруст пишет: «Умьер ${ }^{1}$, о более чем двадцати фразах, говорил мне: “Это невозможно перевести, это не имеет никакого смысла на английском. Я бы это просто опустил". Только благодаря терпению мне удалось найти в них смысл» [Proust, 1932, p. 221].

Ганс-Георг Гадамер в своем труде «Истина и метод», пишет о том, что переводчик должен «углубиться в неясность», он не может ничего оставить «в темноте», даже если отрывок неясен. Неясности, позволенные оригиналу, невозможны в переводе. В трудных пассажах переводчик должен, выразить предельно четко то, «что он понимает». Но в отличие от Гадамера, заявлявшего, что перевод зачастую являет собой выбор между несколькими возможными прочтениями оригинала, Пруст уверен в обратном: пытаясь уловить сущность трудного отрывка, он обнаруживает действительный, единственно заложенный в нем смысл.

Из письма к Константину де Браковану, директору журнала La Renaissance latine: «Я думаю, что этот перевод - не благодаря моему таланту, который ничтожен, но благодаря моей бесконечной добросовестности - будет переводом, которых мало, а именно - настоящей реконструкцией. <..> Если в моем переводе и есть ошибки, то они допущены в местах ясных и легких, так как трудные и неясные пассажи были мною в течение многих лет передуманы, переделаны и углубленны» [Proust, 1932, p. 221]. Добросовестность Пруста подтверждают и современные исследователи, критик и профессор Жан Отре пишет: «В целом, перевод Пруста очень хороший» [Autret, 1955, p. 58].

Первые похвалы Пруст получил уже в 1904 г., когда в издательстве Меркюр де Франс была опубликована «Амьенская библия». Нам интересен отзыв историка Альберта Сореля в газете Le temps от 11 июля 1904 г.: «Он получил помилование, я бы сказал, что он сотворил чудо. Этот убежденный эстет не переводит свои мысли на декадентскую прозу, он пишет, когда размышляет или мечтает, на податливом, гибком французском, свободном, обольстительном, с бесконечными всплесками оттенков и нюансов, но всегда прозрачном» [цит. по Risset, 2007, p. 98]. Этот отзыв предельно точно определяет и отделяет прежнего светского Пруста, «наслаждающегося» автора «Утех и Дней», и автора грядущих «Поисков».

Итак, опыт поиска единственно верного смысла станет для Пруста мотивом творчества и главным сюжетом его романа. Именно благодаря погружениям в «непереводимое» зарождается собственный голос Пруста, который он так упорно искал в «Утехах и Днях» и «Жане Сантее», предшествовавших работе над Рескином.

Вернемся к упомянутому нами выше предисловию к «Сезаму и Лилии» Рескина (позже оно будет опубликовано отдельно под названием «О чтении»). В нем Пруст комментирует процесс чтения и именно в нем зарождается символ порога, препятствия, которое необходимо преодолеть, переступить, чтобы проникнуть в текст «мастера красоты».

Моделью чтения, - пишет Пруст, - является «Божественная комедия» Данте, так как автор книги каждый раз, как Вергилий, оставляет нас в раздумьях и одиночестве в самый важный момент: «Данте не единственный поэт, которого Вергилий довел до порога рая» [Proust, 1988, p. 36]. Просто читать недостаточно, нужно сделать еще один шаг; автор-гид может показать нам рай, но не может дать ключ, который позволит в него проникнуть» [Ibid., p. 58].

В этом же предисловии, будущий автор «Поисков» замечает, что мы открываем настоящий секрет гения только в том, что стерто: большую книгу составляет «то, что молчит», «благородная атмосфера тишины», «замечательный лак, сверкающий жертвой всего того, чего мы не сказали» [Proust, 1988, p. 58].

\footnotetext{
${ }^{1}$ Робер Умьер - переводчик, литератор, известный своими прекрасными переводами Киплинга, помогавший Прусту в работе над произведениями Рескина.
} 
В романе Пруста мы столкнемся с настоящей мистикой загороженного пространства. Одна из постоянных ценностей произведения Пруста - именно недоступность, неприступность, недосягаемость. Процитируем опять же «Блокнот от 1908 года»: «Только то заслуживает быть выраженным, что появилось в глубинах и обычно... эти глубины темны. Эта глубина, эта недосягаемость для нас самих и является единственным признаком значимости...» [Proust, 1976, p. 102].

Препятствие, мешающее проникновению к истине, именно оно стимулирует желание, позволяет зародиться творчеству. «В любви наш счастливый соперник, иными словами, наш враг - это наш благодетель. Он придает существу, вызывающему только бесцветное физическое желание, безмерную ценность, хотя с ним никак и не сопряженную, но нами ему приписываемую. Если бы у нас не было соперников, удовольствие не претворялось бы в любовь» [Пруст, 2007, с. 191]. Препятствие, придающее «безмерную ценность», - знак всего творчества Пруста.

Рассказчик в «Поисках» постоянно сталкивается с подобными препятствиями, отсюда его страсть к расшифровке реальности, которая становится одним из лейтмотивов романа. К своеобразному «декодированию» он прибегает, разгадывая вкус Мадленки, описывая Мартенвильские колокольни, пытаясь проникнуть в тайну трех деревьев в Юдемениле.

Контакт героя с реальной жизнью постоянно описывается как опыт контакта с трудным текстом. «...А ведь уже в Комбре я внимательно отмечал в душе образ, настоятельно требовавший его заметить, - облако, треугольник, колокольню, булыжник, - и чувствовал, что под этими знаками таится нечто совершенно отличное, что я должен постараться раскрыть и его и выраженную им мысль, как дешифруют иероглифические знаки, которые когда-то считали картинками, изображающими предметы. Конечно, эта расшифровка трудна, но только с ее помощью можно прочесть истину» [Там же, с. 120].

Заблуждения и допущенные молодым рассказчиком ошибки объясняются недостаточной компетенцией в истолковании вербального кодекса парижских салонов или недостатком опыта в «грамотном прочтении» женской хитрости. Так, его ошибка насчет добропорядочности и «невинности» девушек в цвету, которые рассказчик «прочел во время задушевных бесед с ними на их лицах», произошла из-за того, что читал он «не вдумываясь, и допустил ошибку при слишком быстром чтении с листа» [Пруст, 1999, с. 568]. И если сначала хитрости Альбертины обескураживают неискушенного Марселя: «Одно и то же выражение лица, одно и то же выражение, которое она употребляла в разговоре, допускало различные толкования; я отступал перед всем этим, как отступает ученик перед трудностями перевода с греческого» [Там же, с. 496], то позже, в «Пленнице», став опытным чтецом, он выберет, скорее, тактику нападения. Неудивительно, что ближе к концу романа рассказчик, дабы узреть то, что действительно скрывается под масками, будет обладать «внутренним стереоскопом» [Proust, 1947, p. 248].

\section{Литература}

Женетт Ж. Пруст - палимпсест // Женетт Ж. Фигуры: В 2 т. М., 1998. Т. 1.

Пруст М. Обретенное время. М., 1999.

Пруст М. Пленница. М., 1990.

Пруст М. Под сенью девушек в цвету. СПб., 1999.

Autret J. L'influence de Ruskin sur la vie, les idées et l'oeuvre de Marcel Proust. Geneve, 1955.

Benjamin W. Essais. Paris, 1983.

Nordlinger M. Lettres à une amie. Manchester, 1942.

Proust M. Le Coté de Guermantes. Paris, 1947. 
Proust M. Contre Sainte-Beuve, précédé de Pastiches et mélanges et suivi de Essais et articles. Paris? 1965.

Proust M. Contre Sainte-Beuve. Paris, 1971.

Proust M. Le Carnet de 1908. Paris, 1976.

Proust M. Matinée chez la Princesse de Guermantes. Cahiers du «Temps retrouvé» / Ed. H. Bonnet, B. Brun. Paris, 1982.

Proust M. Sur la lecture. Arles, 1988.

Proust R., Brach P., Mante-Proust S. Correspondance générale de Marcel Proust en 6 vol. t. 3. Paris, 1932.

Risset J. Traduction et mémoire poétique. Paris, 2007.

Steiner G. After Babel. Oxford, 1975.

Valery P. Variations sur les Bucoliques. Paris, 1957. 